\title{
ROLE OF ANTIOXIDANT ON FRUCTOSE-INDUCED HYPERGLYCAEMIA
}

\author{
KAMEL S., ABDEL-HAMID M.I. ${ }^{*}$, EL-HINDI H.M.A. AND ABDEL-AZIZ S.A. \\ Biochemistry Department, Faculty of Veterinary Medicine, Cairo University, Giza, Egypt. \\ *Corresponding Author: Email- marwa199@yahoo.com
}

\section{Received: December 03, 2013; Accepted: January 02, 2014}

\begin{abstract}
The present study tries to investigate oxidative stress - hyperglycaemia relationship through studying role of ROS and oxidative stress in the pathogenesis of type 2 diabetes mellitus and role of NAC as antioxidant in normalizing that disorders. 80 rats were randomly assigned into four equal groups, 20 rats each; Control group $(C)$ fed on the balanced ration and ordinary drinking water ad-libitum, Fructose fed group $(\mathrm{F})$ fed on the balanced ration and fructose $10 \%(100 \mathrm{~g} / \mathrm{L})$ in drinking water, Fructose and $\mathrm{N}$-acetylcysteine group (FN) fed on the balanced ration and fructose $10 \%(100 \mathrm{~g} / \mathrm{L})$ in drinking water for 4 weeks then injected I/P with $\mathrm{N}$-acetylcysteine in dose of $200 \mathrm{mg} / \mathrm{Kg}$ b.wt. daily for the last six weeks and $\mathrm{N}$-acetylcysteine and Fructose group (NF) fed on the balanced ration and ordinary drinking water and injected I/P with $\mathrm{N}$-acetylcysteine for 4 weeks then given fructose in drinking water for the last six weeks. Blood samples and liver specimens were collected from ten animals from each group after 2 and 10 weeks. The obtained results revealed that fructose administration increased hepatic MDA content and GSPx activity and plasma insulin, insulin resistance and glucose levels. Conversely, excess fructose decreased hepatic GSH content, expression of insulin-receptor's protein gene, SOD, hexokinase and G6PD activities. Those disorders originated a case of type 2 diabetes. Injection of NAC either as treatment or protective relieved all that disorders towards normal condition through its antioxidant influence.
\end{abstract}

Keywords- hyperglycaemia, type 2 diabetes mellitus, Blood samples, liver specimens, insulin-receptor's protein gene

Citation: Kamel S., et al. (2014) Role of Antioxidant on Fructose-Induced Hyperglycaemia. International Journal of Genomics and Proteomics, ISSN: 0976-4887 \& E-ISSN: 0976-4895, Volume 5, Issue 1, pp.-89-94.

Copyright: Copyright@2014 Kamel S., et al. This is an open-access article distributed under the terms of the Creative Commons Attribution License, which permits unrestricted use, distribution and reproduction in any medium, provided the original author and source are credited.

\section{Introduction}

In a normal cell there is balance between formation and removal of free radicals. That free radicals include reactive oxygen species (ROS) which can auto-oxidize glucose and other sugars. During diabetes, glycooxidation or auto-oxidative glycosylation increases and leads to production of advanced glycation endproducts (AGE) such as pentosidine, pyrraline and NG-(carboxymethyl) lysine (CML) [1].

Overproduction or deficiency of ROS may result in impaired homeostasis and associated pathology. In healthy organisms, oxidants are balanced by reductants (antioxidants). This balance can be shifted towards more formation of free radicals or when levels of antioxidants are diminished causing an oxidative stress which results in serious cell damage. Also free radicals have a special affinity for lipids, proteins and nucleic acid (DNA) [2,3].

The antioxidants are either naturally produced in body, or externally supplied through foods and lor supplements (vitamins A, C, E, lycopine and lipoic acid) act as free radical scavengers and therefore can enhance the immune defense. Endogenous antioxidants are either enzymatic as SOD, CAT, GSPx, GST and GR or nonenzymatic as reduced glutathione, albumin and high density lipoprotein [4]. Brownlee [5], stated that hyperglycemia-induced oxidative stress may account for the pathogenesis of all diabetic complications. That pathogenesis is activated by overproduction of super- oxide radicals which increases the following four mechanisms:

- Activation of polyol pathway where glucose is reduced to sorbitol, and both NADPH and reduced glutathione were exhausted.

- Increased formation of advanced glycation end products (AGEs).

- Activation of protein kinase $C$.

- Increase the hexosamine pathway which increases transcription of genes for inflammatory cytokines.

Hyperglycemia, elevated FFA levels, cytokines, and others, increased ROS production and oxidative stress. This results in the activation of multiple stress-sensitive serine/threonine (Ser/Thr) kinase which decreases the extent of insulin-stimulated tyrosine phosphorylation ( $\mathrm{pY}$ ) and consequently, reduction in insulin action (insulin resistance) [6].

Fructose undergoes more rapid glycolysis in the liver than glucose through the regulatory step catalyzed by phosphofructokinase. This leads to enhance in fatty acid synthesis, esterification and increased VLDL secretion, which may raise serum triacylglycerols, LDL cholesterol concentrations and apolipoprotein-B [7]. High levels of fructose may lead to an increase in visceral obesity, which is associated with increased cardiometabolic risk and type II diabetes. High fructose caused maturation and differentiation of fat cells in visceral fat and decreased cells' insulin sensitivity [8]. Treatments 
with antioxidants improve insulin sensitivity in insulin-resistant individuals and/or patients with type 2 diabetes [9].

$\mathrm{N}$-Acetyl Cysteine (NAC) is an antioxidant and a free radicalscavenging agent that increases intracellular glutathione synthesis and activates the cytosolic enzymes involved in glutathione regeneration and glutathione-S-transferase activity. $\mathrm{N}$-acetylcysteine, prevented rise in plasma ROS, attenuated the degree of hyperglycemia and minimizing glycosuria $[10,11]$. N-acetylcysteine improved insulin secretion, moderately decreased blood glucose levels, enhanced beta-cell mass, and decreased apoptosis in the diabetic mice. NAC can protect against $\beta$-cell toxicity and the generation of glycation end products [12]. Also, NAC inhibits the hexosamine pathway and consequntly decrease $\mathrm{H}_{2} \mathrm{O}_{2}$ production [13]. In diabetes, NAC inhibits destruction of the pancreas and helps in prevention of diabetic neuropathy.

Type 2 diabetes mellitus results from a combination of insulin resistance, defects in insulin secretion and hyperglucagonemia. Individuals with insulin receptor abnormalities exhibit severe lipodystrophy and elevated circulating fatty acids [14].

The present study investigates oxidative stress and hyperglycaemia relationship through studying effect of an antioxidant as N-Acetyl Cysteine on fructose over dose- induced hyperglycaemia.

\section{Materials and Methods \\ Materials \\ Experimental Animals}

A total number of 80 , apparently healthy, male albino rats (wister strain) weighing 100-120 grams were reared in Biochemistry department, Faculty of Veterinary Medicine, Cairo Univ., Giza, Egypt. The animals were housed in cages under hygienic measures and standard conditions $\left(25{ }^{\circ} \mathrm{C}, 60 \%\right.$ relative humidity, 12 hours lightdark cycle) for 10 weeks which is the whole experimental period. They were maintained on a balanced diet (17.2\% protein, $3.22 \%$ fat, $4.17 \%$ fibers, $2800 \mathrm{Kcal} / \mathrm{Kg}$ ration). Drinking water and diet were offered daily in amounts enough to satisfy their nutritional requirements. The animals were acclimatized for 2 weeks before the experiment.

\section{Experimental Design}

Rats were randomly assigned into four equal groups, 20 rats each:

\section{Negative Control Group (C)}

Rats were fed on the balanced ration and ordinary drinking water ad -libitum

\section{Fructose Fed Group (F)}

Rats were fed on the balanced ration and fructose $10 \%(100 \mathrm{~g} / \mathrm{L})$ in drinking water ad-libitum throughout the whole experimental period.

\section{Fructose and N-acetylcysteine Group (FN)}

Rats were fed on the balanced ration and fructose $10 \%(100 \mathrm{~g} / \mathrm{L})$ in drinking water ad-libitum for 4 weeks. After that 4 weeks, fructose administration was continuoued in combination with $\mathrm{I} / \mathrm{P}$ injection of $\mathrm{N}$-acetylcysteine in dose of $200 \mathrm{mg} / \mathrm{Kg}$ b.wt. daily for the last six weeks.

\section{$\mathrm{N}$-acetylcysteine and Fructose Group (NF)}

Rats were fed on the balanced ration and ordinary drinking water ad -libitum and injected I/P with $\mathrm{N}$-acetylcysteine in dose of $200 \mathrm{mg} / \mathrm{Kg}$ b.wt. daily for 4 weeks. After those 4 weeks, rats were given fructose $10 \%(100 \mathrm{~g} / \mathrm{L})$ in drinking water ad-libitum in combination with $\mathrm{N}$-acetylcysteine injection for the last six weeks.

\section{Sample Collection}

Blood samples and liver specimens were collected from ten animals from each group after 2 and 10 weeks (end of the experiment).

\section{Blood Collection}

Animals were starved for 12 hours, anaesthetized with diethyl ether before collection of blood samples from the medial canthus of eye into sodium fluoride tubes and EDTA tubes for separation of plasma for determination of glucose and insulin respectively. EDTAted whole blood used for determination of G6PDH.

\section{Liver Collection}

After sacrificing of animals, liver specimens were rapidly excised and washed with ice cold saline $(0.9 \% \mathrm{NaCl})$ to get rid of debris and blood then were stored at $-20^{\circ} \mathrm{C}$. for homogenization and biochemical analysis.

\section{Biochemical Analysis}

Concentration of plasma glucose and G6PDH activity were determined by techniques described by Tietz [15], Sood, et al. [16], Lubin and Oski [17] respectively. Plasma insulin concentration was measured according to the manufacture of insulin (rat) ELIZA DRG kit [18]. Hepatic hexokinase activity was performed to Bergmeyer, et al. [19]. Hepatic contents of malondialdehyde (MDA), reduced glutathione (GSH) and total proteins were determined according to techniques of Albro, et al. [20], Ellman [21] and Bradford [22]. Hepatic superoxide dismutase (SOD) activity was estimated according to techniques of Marklund and Marklund [23], modified by Nandi and Chtterjee [24] and while glutathione peroxidase (GSH-Px) activity was determined by technique of Rotruck, et al. [25]. Homeostasis model assessment of insulin resistance (HOMA-IR) was used as an index to measure the degree of insulin resistance and was calculated by the formula:

$$
\text { insulin }(\mu \mathrm{U} / \mathrm{ml}) \mathrm{X} \text { glucose }(\mathrm{mg} / \mathrm{dl}) / 405 \text {. }
$$

\section{Molecular Biological Analysis \\ Detection of Insulin Receptor Gene \\ Total RNA Extraction}

RNA isolated from liver tissue by GF-1 Total RNA Extraction Kit according to the manufacture instructions. The extracted total RNA was stored at $-20^{\circ} \mathrm{C}$. Its yield and purity was assessed at 260 and $280 \mathrm{~nm}$ respectively.

\section{Reverse Transcriptase Polymerase Chain Reaction (RT-PCR)}

It was performed by Viva 2-steps RT-PCR Kit according to the manufacture instructions.

\section{Real Time PCR}

The reaction mixture consisted of $1 \mu \mathrm{l}$ CDNA, $0.5 \mathrm{mM}$ of each primer (insulin receptor and GAPDH as internal control) which are illustrated in table, iQ SYBR GREEN PERMIX (BIO-RAD 170-880) in a total volume of $20 \mu$ l. PCR amplification and analysis were achieved using BIO-RAD iCycler thermal cycler and the MyiQ real-time PCR detection system. The Fast Start polymerase was activated and cDNA denatured by a pre incubation for $10 \mathrm{~min}$ at $95^{\circ} \mathrm{C}$, the tem- 
plate was amplified for 40 cycles of denaturation programmed for $10 \mathrm{~s}$ at $95^{\circ} \mathrm{C}$, annealing of primers at $60^{\circ} \mathrm{C}$ programmed for $30 \mathrm{~s}$, and extension at $72^{\circ} \mathrm{C}$ programmed for $30 \mathrm{~s}$. Fluorescent data were acquired during each extension phase [26] .

The $\triangle C T$ value is calculated by the subtraction of the GAPDH CT from each P53 CT.

- The $\triangle \Delta C T$ value is calculated by subtraction of the control $\Delta C T$ from each P53 $\triangle \mathrm{CT}$.

- The expression relative to control is calculated using the equation 2- $\triangle \Delta C T$.

\section{Results}

Administration of fructose increased hepatic MDA but decreased glutathione contents and SOD activity significantly than control, NAC-treated (FN) and NAC-protected (NF) groups at the end of the experiment. On the other hand, fructose activated GSPx significantly higher than control and (FN) groups but stilled lower than (NF) group.

Injection of NAC either as treatment (FN) or protective (NF) decreased significantly hepatic MDA lower than not only $(F)$ group but also control group. NAC as a protective (NF group) increased significantly glutathione content and GSPx activity higher than other groups (except glutathione in control group) but failed in protection of SOD against fructose effect. Conversely, injection of NAC as treatment (FN group) increased SOD activity significantly higher than other groups.

Fructose administration increased significantly plasma insulin level and insulin resistance but decreased expression of insulin receptor's protein gene than all other groups at the end of the experiment.
NAC injection either as treatment (FN) or protective (NF) increased significantly plasma insulin level and insulin resistance higher than control group but stilled lower than fructose group. Conversely, NAC injection increased expression of insulin receptor's protein higher than fructose group but stilled lower than control group after 10 weeks.

Fructose administration increased significantly plasma glucose concentration but decreased hexokinase and G6PDH activities than all other groups at the end of the experiment.

NAC injection either as treatment (FN) or protective (NF) decreased plasma glucose concentration lower than fructose group but still higher than control group. On the other hand, NAC increased significantly hexokinase and G6PDH activities higher than F-group but still lower than control group after 10 weeks.

\section{Discussion}

Administration of fructose stimulated glycolytic pathway and citric acid cycle through activation phosphofructokinase I enzyme. This may increase production of electron donors as $\mathrm{NADH} / \mathrm{H}^{+}$from glycolytic glyceraldehyde-3-phosphate dehydrogenase enzyme (GAD $\mathrm{PH})$ and the tricarboxylic acid cycle. Transfer of single electrons from that excess electron donors to oxygen, produces superoxide radicals and other reactive oxygen species (ROS). Over production of ROS disturbed the oxidative/antioxidative balance towards an oxidative stress condition. Those events interpret the observed increase of MDA concentration and depletion of reduced glutathione content as well as inhibition of SOD activity in liver of fructoseadministered group after 10 weeks [Table-1]. That obtained data revealed unexpected significant increase in GSPx activity in spite of depletion of reduced glutathione content.

Table 1- Changes of oxidative stress and some antioxidative markers in rats under influences of Fructose and NAC

\begin{tabular}{|c|c|c|c|c|c|}
\hline \multirow{2}{*}{ Parameter } & \multirow{2}{*}{ Time (Weeks) } & \multicolumn{4}{|c|}{ Groups } \\
\hline & & Control (C) & Fructose $(\mathbf{F})$ & Fructose \& NAC (FN) & NAC \& Fructose (NF) \\
\hline \multirow{2}{*}{ MDA ( $\mu \mathrm{M} / \mathrm{mg}$ protein) } & 2 & $1.89 \pm 0.20 \mathrm{bA}$ & $2.36 \pm 0.29 \mathrm{abA}$ & $2.59 \pm 0.30 \mathrm{aA}$ & $1.68 \pm 0.15 b A$ \\
\hline & 10 & $2.10 \pm 0.12 \mathrm{bA}$ & $2.99 \pm 0.30 \mathrm{aA}$ & $1.63 \pm 0.09 \mathrm{bcB}$ & $1.34 \pm 0.07 \mathrm{cA}$ \\
\hline \multirow{2}{*}{ Glutathione ( $\mu \mathrm{mol} / \mathrm{mg}$ protein) } & 2 & $0.35 \pm 0.013 a b A$ & $0.33 \pm 0.025 \mathrm{abA}$ & $0.30 \pm 0.017 \mathrm{bA}$ & $0.36 \pm 0.004 \mathrm{aA}$ \\
\hline & 10 & $0.39 \pm 0.022 a A$ & $0.19 \pm 0.021 \mathrm{cB}$ & $0.28 \pm 0.031 \mathrm{bA}$ & $0.37 \pm 0.022 \mathrm{aA}$ \\
\hline \multirow{2}{*}{ SOD (U/g protein) } & 2 & $50.70 \pm 3.38 \mathrm{bB}$ & $49.00 \pm 0.93 \mathrm{bB}$ & $48.14 \pm 4.10 \mathrm{bB}$ & $85.38 \pm 3.10 \mathrm{aA}$ \\
\hline & 10 & $69.62 \pm 1.84 \mathrm{aA}$ & $50.76 \pm 2.46 \mathrm{bB}$ & $73.00 \pm 3.26 \mathrm{aA}$ & $45.42 \pm 2.79 \mathrm{bB}$ \\
\hline \multirow{2}{*}{ GSPx (nmol /mg protein) } & 2 & $0.08 \pm 0.015 \mathrm{bA}$ & $0.08 \pm 0.007 \mathrm{bB}$ & $0.07 \pm 0.005 \mathrm{bB}$ & $1.61 \pm 0.002 \mathrm{aA}$ \\
\hline & 10 & $0.09 \pm 0.009 \mathrm{cA}$ & $0.20 \pm 0.010 \mathrm{bA}$ & $0.06 \pm 0.001 \mathrm{~dB}$ & $1.61 \pm 0.003 a A$ \\
\hline \multicolumn{6}{|c|}{$\begin{array}{l}\text { NAC: } N \text {-acetyl cysteine, MDA: Malondialdehyde, SOD: Superoxide dismutase, GSPx: Glutathione peroxidase. } \\
\text { Different small letters indicate significant variation between groups at the same week (Rows) at } P<0.05 \text {. } \\
\text { Different capital letters indicate significant variation between different weeks in the same group(Column) at } P<0.05 \text {. }\end{array}$} \\
\hline
\end{tabular}

Ceriello [27], stated that the superoxide anion itself inhibits the key glycolytic enzyme glyceraldehyde-3-phosphate dehydrogenase (GA $\mathrm{DPH}$ ), and consequently, glucose and glycolytic intermediates spill into the polyol and hexosamine pathways, as well as additional pathways that culminate in protein kinase $C$ activation and intracellular AGE formation.

El-missiry, et al. [28], Melo, et al. [29], Sanders, et al. [30] found decrease in GSH concentration in liver of diabetic rats. Also Pasaoglu, et al. [31], recorded decreasing in GSH content in liver of type II diabetic patients.

Oda, et al. [32] reported that during hyperglycemia and insulin resistance, SOD is inactivated by glycation of specific lysine residues. SOD activity was inhibited in type II diabetic patients [31]. Marjani [33], found decrease in SOD activity in type II diabetic patients. That may be attributed to developed hyperglycemia with subsequent depletion in $\mathrm{Cu}^{++}$ions which is essential cofactor for SOD. Hyperglycemia is accompanied with loss of $\mathrm{Cu}^{++}$and SOD is inactivated by glycosylation [34].

Administration of fructose significantly increased GSPx activity all over the experimental period. The observed activation of GSPx after fructose administration may be attributed to increased production of $\mathrm{H}_{2} \mathrm{O}_{2}$ and MDA with subsequent depletion of $\mathrm{GSH}$ content.

Pasaoglu, et al. [31] recorded an increase in GSPx activity in type II diabetic patients. The increase in GSPx activity in the liver of diabetic patients may be a compensatory response to oxidative stress of hyperglycemia [35].

A higher quantification cycle threshold corresponding to a lower amount of mRNA was observed in the fructose treated group. The produced oxidative stress through ROS participated in attenuation of expression of insulin-receptor's protein gene which was attained 
in rats of F-group after 10 weeks, [Table-2]. The observed increase in expression of that gene after 2 weeks only may be a compensatory mechanism where hepatic MDA and glutathione contents as well as SOD and GSPx activities were not significantly changed than normal rats [Table-1]. That observed attenuation of expression of insulin-receptor's protein gene resulted in significant increase cellular insulin resistance and consequently higher plasma insulin concentration after 10 weeks [Table-2].

Table 2- Changes in insulin, insulin resistance and real time PCR of insulin receptor in rats under influences of Fructose and NAC.

\begin{tabular}{lccccc|}
\hline & Time (Weeks) & Control (C) & Fructose (F) & Fructose \& NAC (FN) & NAC \& Fructose (NF) \\
\hline Insulin ( $\mathrm{p} \mathrm{mol} / \mathrm{ml}$ ) & 2 & $36.89 \pm 0.57 \mathrm{abA}$ & $39.63 \pm 0.94 \mathrm{aB}$ & $39.19 \pm 0.63 \mathrm{aA}$ & $35.79 \pm 0.75 \mathrm{bB}$ \\
& 10 & $34.80 \pm 0.52 \mathrm{cA}$ & $50.16 \pm 0.89 \mathrm{aA}$ & $41.67 \pm 0.85 \mathrm{bA}$ & $43.72 \pm 0.82 \mathrm{bA}$ \\
Insulin Resistance & 2 & $1.14 \pm 0.05 \mathrm{bA}$ & $1.36 \pm 0.05 \mathrm{aB}$ & $1.31 \pm 0.04 \mathrm{aB}$ & $1.09 \pm 0.03 \mathrm{bB}$ \\
& 10 & $1.21 \pm 0.05 \mathrm{cA}$ & $2.06 \pm 0.05 \mathrm{aA}$ & $1.58 \pm 0.04 \mathrm{bA}$ & $1.70 \pm 0.03 \mathrm{bA}$ \\
Quantitative Real Time PCR & 2 & 1 & 1.34 & 1.85 & 0.52 \\
NAC: $N$-acetyl cysteine. Different small letters indicate significant variation between groups at the same week (Rows) at $P<0.05$. & 0.55 \\
Different capital letters indicate significant variation between different weeks in the same group(Column) at $P<0.05$. & \\
\hline
\end{tabular}

Bezerra, et al. [36], recorded decreased insulin-induced insulin receptor phosphorylation in the liver of fructose fed rats. Also Catena, et al. [37], recoded a decrease in skeletal and hepatic insulin receptor number, determined by an in situ autoradiography technique, as well as a decrease in their gene expression was found by $66 \%$ fructose feeding for 2 weeks in rats. Decreased insulin stimulated-tyrosine phosphorylation of insulin receptors and insulin receptor substrate 1 (IRS-1) were demonstrated in the fructose-fed hamsters [38].

High fructose consumption can induce insulin resistance, impaired glucose tolerance, hyperinsulinemia, and hypertension in animal models [39].

Axelsen, et al. [40], stated that, in rodents, there is no doubt that high-fructose feeding cause insulin resistance; therefore it is often used in many studies as a dietary model of insulin resistance.

Increasing of cellular insulin resistance resulted not only in over secretion of insulin but also weakness in insulin-cellular response which was reflected as significant increase of plasma glucose level (hyperglycaemia) accompanied by inhibition in the activity of both hexokinase and G6PDH enzymes in liver of fructose-fed rats after 10 weeks [Table-3].

Increasing of insulin resistance propagated the oxidative stress through:

- Inhibition of G6PDH activity causing depletion of NADPH and consequently exhaustion of GSH.

- Hyperglycemia may activate polyol pathway through activation of aldose reductase where glucose is reduced to sorbitol on the expense of NADPH with subsequent interference with reduction of GS-SG into GSH.

Also increasing of insulin resistance would cause inhibition of phosphofructokinase II and stoppage of phosphorylation of fructose-6phosphate into fructose-2,6-bisphosphate and consequently inhibition of phosphofructokinase I leading to down-regulation of glycolysis.

This study through its obtained data can reveal that excess fructose feeding may lead to type 2 diabetes through over generation of ROS, exhaustion of antioxidant mechanisms and establishment of oxidative stress condition which produce the insulin resistance.

Fructose feeding caused downregulation of G6PDH and 6-phospho gluconate dehydrogenase enzyme. That mechanism results in either depletion of NADPH or inhibition of reduction of NADP. Defficiency of NADPH interferes with reduction of glutathione and consequently decreases GSH content [41].
Injection of NAC either as treatment (FN-group) or protective (NFgroup) treated or protected rats from diverse and harmful effects (oxidative stress and insulin resistance) of fructose overload.

NAC through stimulation of glutathione synthesis by activation of glutamyl-cystein synthetase supported the antioxidant mechanisms. Therefore hepatic glutathione content and SOD, GSPx activities were increased and MDA content was decreased significantly in both FN and NF-groups than F-group [Table-1].

NAC stimulates glutathione synthesis, enhances glutathione-Stransferase activity, promotes liver detoxification by inhibiting xenobiotic biotranformation, and is a powerful nucleophile capable of scavenging free radicals. NAC is GSH precursor and also increases the efficiacy of such enzymes as GSSG reductase. This enzyme recycles glutathione disulphide (GSSG) back to GSH [42]

NAC effect in enhancing endogenous SOD activity, which may have resulted from its capability in attenuating tumor necrosis factoralpha-induced reduction of SOD activity [43]. NAC can inhibit NADPH oxidase and ROS production and consequently reduce oxidative stress [44].

As the antioxidant NAC re-established normal oxidative/antioxida tive balance, expression of insulin receptor's protein gene began to increase with subsequent decrease in insulin resistance and plasma insulin level in rats of FN and NF-groups. The low amounts of insulin mRNA detected in the fructose treated group might be upregulated in the NAC treated group. NAC was proved to be more effective as protective than treatment where NF- group showed the highest level of IR mRNA in the experimental groups [Table-2].

NAC can protect $\beta$ - cell against toxicity and formation of AGE [12]. Antioxidants as NAC counteracted the hexosamine pathway with subsequent lowering of $\mathrm{H}_{2} \mathrm{O}_{2}$ production and consequently protect $\beta$ - cell function [13].

NAC can prevent the insulin resistance-induced hyperglycemia [45].

As a result of lowering in insulin resistance, cellular insulin sensitivity increased and consequently plasma glucose level started to decrease and activities of hepatic hexohinase and G6PDH increased in FN and NF-groups than F-group at end of experiment [Table-3].

It has been found that antioxidants, improve insulin sensitivity [46]. Several clinical trials have demonstrated that treatment with antioxidants improve insulin sensitivity in insulin-resistant individuals and/ or patients with type 2 diabetes [9]. The protective effects of antioxidants on oxidative stress-induced insulin resistance could relate to their ability to preserve the intracellular redox balance (neutralizing ROS) [47]. 
Table 3- Changes in blood glucose level, and hepatic Hexokinase \& G6PD activities in rats under influences of Fructose and NAC

\begin{tabular}{|c|c|c|c|c|c|}
\hline Parameter & Time (Weeks) & Control (C) & Fructose (F) & Fructose \& NAC (FN) & NAC \& Fructose (NF) \\
\hline \multirow{2}{*}{ Glucose (mg/100 ml) } & 2 & $91.28 \pm 2.49 \mathrm{aA}$ & $95.71 \pm 1.93 \mathrm{aB}$ & $94.81 \pm 1.3 \mathrm{aB}$ & $95.05 \pm 3.24 \mathrm{aB}$ \\
\hline & 10 & $91.56 \pm 3.62 \mathrm{cA}$ & $111.52 \pm 3.62 \mathrm{aA}$ & $102.20 \pm 2.8 \mathrm{bA}$ & $108.70 \pm 3.62 \mathrm{abA}$ \\
\hline \multirow{2}{*}{ Hexokinase (U/mg protein ) } & 2 & $2.36 \pm 0.064 \mathrm{aA}$ & $2.29 \pm 0.068 a b A$ & $2.18 \pm 0.030 \mathrm{bA}$ & $2.43 \pm 0.051 \mathrm{aA}$ \\
\hline & 10 & $2.06 \pm 0.024 \mathrm{aB}$ & $0.56 \pm 0.017 \mathrm{~dB}$ & $1.45 \pm 0.069 \mathrm{bB}$ & $1.23 \pm 0.047 \mathrm{cB}$ \\
\hline \multirow[t]{2}{*}{ G6PDH (U/g Hb) } & 2 & $21.60 \pm 0.92 \mathrm{aB}$ & $19.06 \pm 0.88 \mathrm{bA}$ & $17.75 \pm 0.80 \mathrm{bA}$ & $19.51 \pm 0.65 \mathrm{bA}$ \\
\hline & 10 & $22.83 \pm 0.65 \mathrm{aB}$ & $13.15 \pm 0.38 \mathrm{cB}$ & $19.31 \pm 0.71 \mathrm{bA}$ & $19.41 \pm 0.24 \mathrm{bA}$ \\
\hline
\end{tabular}

\section{Conclusion}

This study can conclude that excess fructose feeding may increase ROS production and generate a case of oxidative stress which affects expression of insulin-receptor's protein gene. That will cause insulin resistance and decrease insulin-cellular sensitivity with its metabolic disorders and type 2 diabetes mellitus.

Conflicts of Interest: None declared.

\section{References}

[1] Horie K., Miyata T., Maeda, K. and Miyata S.I. (1997) J. Clin. Invest., 12, 2995-3004.

[2] D'Autreaux B. and Toledano M.B. (2007) Nat. Rev. Mol. Cell Biol., 8(10), 813-824.

[3] Velavan S. (2011) Pharmacologyonline, 1062-1077.

[4] Valko M., Rhodes C.J., Moncol J. and Izakovic M. (2006) Chem. Biol. Interact., 160, 38-40.

[5] Brownlee M. (2001) Nature, 414, 813-820.

[6] Birnbaum M.J. (2001) J. Clin. Invest., 108, 655 -659.

[7] Le K.A. and Tappy L. (2006) Curr. Opin. Clin. Nutr. Metab. Care, 9(4), 469-475.

[8] Pollock N.K., Bundy V., Kanto W., Davis C.L., Bernard P.J., Zhu H., Gutin B. and Dong Y. (2011) Journal of Nutrition, 142(2), 251-257.

[9] Jacob S., Lehmann R., Rett K. and Häring H.U. (2000) Antioxidants in Diabetes Management, Marcel Dekker, NY, 319-338.

[10]Tanaka Y., Gleason C.E., Tran P.O., Harmon J.S. and Robertson R.P. (1999) Proc. Natl. Acad. Sci., 96, 10857-10862.

[11]Motoki A. (2007) Curr. Opin. Pharmacol., 7(4), 355-359.

[12]Ho E., Chen G. and Bray T.M. (2000) Free Radic. Biol. Med., 28, $604-614$.

[13]Kaneto H., Xu G., Song K.H., Suzuma K., Bonner-Weir S., Sharma A. and Weir G.C. (2001) J. Biol. Chem., 276, 31099 31104.

[14]Hegele R.A. (2003) Trends Endocrinol. Metab., 14(8), 371-377.

[15]Tietz N.W. (1995) Clinical Guide to Laboratory Tests, 3rd ed., Philadelphia, WB Saunders, 268-273.

[16]Sood S.K., Madan N., Talwar N., Maheshwari A., Jayant D., Bhargava S.K. (1981) Indian J. Pathol. Microbiol., 24(2), 89-99.

[17]Lubin B.H., Oski F.A. and Brigandi E.P. (1967) The Journal of Pediatrics, 70(5), 788-792.

[18]Olsson R. and Carlsson P.O. (2005) Diabetologia, 48(3), 469476.

[19]Albro P.W., Corbett J.T. and Schroeder J.L. (1986) Journal of
Biochemistry, 261, 4889-4894.

[20]Ellman G.L. (1959) Arch. Biochem. Biophys., 82, 70-77.

[21]Bradford M.M. (1976) Anal. Biochem., 72, 248-254.

[22]Marklund S. and Marklund G. (1974) European Journal of Biochemistry, 47, 469-474.

[23]Nandi A. and Chatterjee I.B. (1988) J. Biosci., 13(3), 305-315.

[24]Rotruck J.T., Pope A.L., Ganther H.E., Swanson A.B., Hafeman D.G. and Hoekstra W.G. (1973) Science, 179(4073), 588-590.

[25]Livak K.J. and Schmittgen T.D. (2001) Methods, 25(4), 402408.

[26]Ceriello A. (2003) Diabetes Care, 26, 1589-1596.

[27]El-Missiry M.A. and El Gindy A.M. (2000) Ann. Nutr. Metab., 44 (3), 97-100.

[28]Melo S.S., Arantes M.R., Meirelles M.S., Jordao A.A. and Vannucchi H. (2000) Acta Diabetol., 37(1), 33-39.

[29]Sanders R.A., Rauscher F.M. and Watkins J.B. (2001) J. Biochem. Mol. Tox., 15, 143-149.

[30]Pasaoglu H., Sancak B. and Bukan N. (2004) Tohoku J. Exp. Med., 203, 211-218.

[31]Oda A., Bannai C., Yamoka T., Katori T., Malsushima T. and Yamashitak I. (1994) Horm. Metab. Res., 26, 1-4.

[32]Marjane A. (2006) Journal of Ardebil Medical University, 6(2), 183-187.

[33]Hamden K., Carreau S., Jamoussi K., Miladi S., Lajmi S. and Aloulou D. (2009) J. Nutr. Sci. Vitaminol., 55(3), 215-222.

[34]Bezerra R.M., Ueno M., Silva M.S., Tavares D.Q., Carvalho C.R. and Saad M. (2000) J. Nutr., 130, 1531-1535.

[35]Ehsaneh T., Mahmoud D., Ahmad S., Ali M., Abolghasem D., Mostafa Q. (2012) J. Diab. \& Metab. Disorders, 11(3).

[36]Catena C., Giacchetti G., Novello M., Colussi G., Cavarape A. and Sechi L.A. (2003) Am. J. Hypertens., 16, 973-978.

[37]Mielkem J.G., Taghibiglou C. and Liu L. (2005) J. Neuroche., 93, 1568-1578.

[38]Vos M., Kimmons J., Gillespie C., Welsh J. and Blanck H. (2008) Medscape J. Med., 10(7), 160.

[39]Axelsen L.N., Pedersen H.D., Petersen J.S., Holstein-Rathlou N.H. and Kjolbye A.L. (2010) J. Pharmacol. Toxicol. Methods, 61(3), 292-296.

[40]Giardino I., Edelstein D. and Brownlee M. (1996) J. Clin. Invest., 97, 1422-1428.

[41]Miquel J., Ferrandiz E., De Juan I., Sevila I. and Martinez M. (1995) Eur. J. Pharmacol., 292, 333-335.

[42]Xia Z., Liu M., Wu Y., Sharma V., Luo T. and Ouyang J. (2006) 
Eur. J. Pharmacol., 550, 134-142.

[43]Shen G.X. (2010) Can. J. Physiol. Pharmacol., 88, 241-248.

[44]Haber C.A., Lam T.K., Yu Z., Gupta N., Goh T., Bogdanovic E., Giacca A, and Fantus I.G. (2003) Am. J. Physiol. Endocrinol. Metab., 285, E744-E753.

[45]Maddux B.A., See W., Lawrence J.C., Goldfine A.L., Goldfine I.D. and Evans J.L. (2001) Diabetes, 50, 404-410.

[46]Yuan M., Konstantopoulos N., Lee J., Hansen L., Li Z.W., Karin M. and Shoelson S.E. (2001) Science, 293, 1673 -1677. 